UDC 629.76

O. D. NIKOLAYEV, I. D. BASHLIY, N.V. KHORIAK, S.I. DOLGOPOLOV

\title{
Evaluation of the high-frequency oscillation parameters of a liquid-propellant rocket engine with an annular combustion chamber
}

\author{
Institute of Technical M echanics \\ of the National Academy of Sciences of U kraine and the State Space Agency of U kraine \\ 15 Leshko-Popel St., D nipro 49005, U kraine; e-mail: odnikolayev@ gmail.com
}

\begin{abstract}
The high-frequency instability (HF instability) of a liquid-propellant rocket engine (LPRE) during static firing tests is often accompanied by a significant increase in dynamic loads on the combustion chamber structure, often leading to the chamber destruction. This dynamic phenomenon can also be extremely dangerous for the dynamic strength of a liquid-propellant rocket engine with an annular combustion chamber. Computation of the parameters of acoustic combustion product oscillations is important in the design and static firing tests of such rocket engines. The main aim of this paper is to develop a numerical approach to determining the parameters of acoustic oscillations of combustion products in annular combustion chambers of liquid-propellant rocket engines taking into account the features of the configuration of the combustion space and the variability of the physical properties of the gaseous medium depending on the axial length of the chamber. A numerical approach is proposed. The approach is based on mathematical modeling of natural oscillations of a "shell structure of an annular chamber - gas" coupled dynamic system by using the finite element method.

Based on the developed finite-element model of coupled spatial vibrations of the structure of the annular combustion chamber and the combustion product oscillations, the oscillation parameters of the system under consideration (frequencies, modes, and effective masses) for its dominant acoustic modes, the vibration amplitudes of the combustion chamber casing, and the amplitudes of its vibration accelerations can be determined. The operating parameters of the liquid-propellant rocket engine potentially dangerous for the development of thermoacoustic instability of the working process in the annular combustion chamber can be identified. For the numerical computation of the dynamic gains (in pressure) of the combustion chamber, a source of harmonic pressure excitation is introduced to the finite element model of the dynamic system "shell structure of an annular configuration - gas" (to the elements at the start of the chamber fire space).

The developed approach testing and further analysis of the results were carried out for an engine with an annular combustion chamber (with a ratio of the outer and inner diameters of 1.5) using liquid oxygen - methane as a propellant pair.

The system shapes and frequencies of longitudinal, tangential and radial modes are determined. It is shown that the frequency of the first acoustic mode in the case of a relatively low stiffness of the combustion chamber casing walls can be reduced by 40 percent in comparison with the frequency determined for a casing with rigid walls.
\end{abstract}

Keywords liquid propellant rocket engine, annular combustion chamber, methane-oxygen propellant, highfrequency engine instability, oscillation frequencies.

1. Hall Joshua N., Hartsfield Carl R., Simmons Joseph R., Branam Richard D. Performance \& Thrust-to-Weight Optimization of the Dual Expander Aerospike Nozzle Upper Stage Rocket Engin AIAA Report. 2012. 50260651/Q0BD. URL: https://arc.aiaa.org/doi/abs/10.2514/6.2011-419 (Last accessed on October 25, 2020).

2. Bell G., Weightman J., Knast T., Tan D., Mason-Smith N., Wong M., Jurg M. An additively manufactured CNG/GOX aerospike rocket engine: design process. 68th International Astronautice Congress. (Adelaide, Australia, 25 - 29 September, 2017) Adelaide, Australia, 2017. IAC-17C4.1.12.

URL: https://iafastro.directory/iac/paper/id/39522/summary/ (Last accessed on October 25, 2020)

3. Bacha C., Schöngarth S., Bust B., Propst M., Sieder-Katzmann J., Tajmar M. How to steer an aerospike. 69th International Astronautical Congress. (Bremen, October, 2018). Bremen, 2018 IAC-18-C4.3.15 URL: https://www.researchgate.net/publication/328145907 How to steer an_aerospike (Last accessed on October 25, 2020).

4. Natanzon M. S. Combustion Instability. Moscow: Mashinostroyeniye, 1986. (in Russian). 
5. Dranovsky M. L. Combustion Instabilities in Liquid Rocket Engines: Testing and Development Practices in Russia. AIAA. Progress in Astronautics and Aeronautics. 2007. V. 221. 321 pp. https://doi.org/10.2514/4.866906

6. Il'chenko M. A., Kryutchenko V. V., Mnatsakyan Yu. S. Stability of the Working Process in Flyin! Vehicle Engines. Moscow: Mashinostroyeniye, 1995. (in Russian).

7. Klein S., Börner M., Hardi J. S., Suslov D., Oschwald M. Injector-coupled thermoacoustic instabilities in an experimental LOX-methane rocket combustor during start-up. CEAS Space Journal. 2020. Pp. 267-279.

URL: https://www.ist.rwth-aachen.de/go/id/raks/file/794257/lidx/1/ (Last accessed on October 25, 2020).

https://doi.org/10.1007/s12567-019-00294-4

8. Liquid propellant rocket. ombustion instability. National Aeronautics and Space Administration Washington, 1972. 637 pp. SP-194. URL:https://ntrs.nasa.gov (Last accessed on October 25, 20ć

9. Kaess R., Koeglmeier S., Sattelmayer T., Schulze M., Oschwald M., Hardi J. HF combustion stability.

Research activities in Germany. Space Propulsion Conference. Rome, 2016. 12 pp. SP2016_3124816.

URL: https://elib.dlr.de/107846/1/Kaess2016_SP2016_3124816.pdf (Last accessed on October 2! 2020).

10. Kohnke P. Ansys Inc. Theory Manual. 001369. Twelfth Edition. Canonsburg: SAS IP, 2001, 12 pp.

11. Zienkiewicz O. C. The Finite Element Method in Engineering Science. Moscow: Mir, 1975. 541 pp. (in Russian).

12. Lependin L. F. Acoustics. Moscow: Vysshaya Shkola, 1978. 448 pp. (in Russian).

13. Roache P. Computational Fluid Dynamics. Moscow: Mir, 1980. 618 pp. (in Russian).

14. Bathe K. J. Finite Element Procedures.

Prentice-Hall: Englewood Cliffs, 1996.

15. Zienkiewicz O. C., Newton R. E. Coupled vibrations of a structure submerged in a compressib fluid.

Proceedings of the Symposium on Finite Element Techniques. University of Stuttgart. Germany. June 1969.

URL: https://repository.tudelft.nl/islandora/object/uuid\%3A27785b4f-3709-4fa9-a189-6ce1d33655 (Last accessed on October 25, 2020).

16. Oschwald M., Faragó Z., Searby G., Cheuret F. Resonance frequencies and damping of a combustor

acoustically coupled to an absorber. Journal of Propulsion and Power. 2008. V. 24. No. 3. Pp. 52 533.

URL:

https://www.researchgate.net/publication/225000485 Resonance Frequencies and Damping of

C̄ylindrical_Combustor_Acoustically_Coupled_to_an_Absorber (Last accessed on October 25, 2020).

https://doi.org/10.2514/1.32313

17. Crocco L. Cheng S.I. Theory of Combustion Instability in Liquid Propellant Rocket Motors. . 
London:

Butterworths Scientific Publications, New York: Interscience Publishers Inc., 1956. 200 pp.

URL: https://ui.adsabs.harvard.edu/abs/1957JFM.....2..100H/abstract (Last accessed on October : 2020).

https://doi.org/10.1017/S0022112057210774

Received on November 17, 2020,

in final form on December 20, 2020 